\title{
TREND CAKUPAN KUNJUNGAN IBU HAMIL (K4) DAN PERTOLONGAN PERSALINAN OLEH TENAGA KESEHATAN DI PROVINSI JAWA TIMUR
}

\author{
TREND SCOPE OF ANTENATAL CARE (K4) AND BIRTH ATTENDANTS BY HEALTH \\ WORKER IN EAST JAVA PROVINCE
}

\author{
Ananda Riska Mita Izati \\ Fakultas Kesehatan Masyarakat, Universitas Airlangga \\ J1. Mulyorejo Kampus C Unair, Surabaya 60115 \\ Alamat Korespondensi: \\ E-mail: anandamita28@gmail.com
}

\begin{abstract}
The health status of mothers and children in Indonesia is still a concern because the decline maternal and infant mortality rates into the development goal of health. The low public awareness of health services by health worker is a factor to consider. This study aims to determine the trend of scope of antenatal care (K4) and birth attendants by skilled health personnel by city in East Java Province 2011-2015. This study used a cross sectional study design. The result obtained $K 4$ scope in general has increased, showed improvements in the community's access to maternal health care provided by health workers, nor with the scope birth attendants by skilled health personnel has increased due to improved maternal health care because it is assumed that pregnant women who receive antenatal care $K 4$ be helped her labor the possibility of health workers. The conclusion of this study is in the next 5 years (20112015), the pattern of coverage of antenatal care (K4) and birth attendants by skilled health personnel in East Java province tends to increase, it is expected to improve antenatal care scope $K 4$ will increase the scope birth attendants by skilled health personnel.
\end{abstract}

Keywords: Trend, K4, birth attendants, East Java 


\begin{abstract}
ABSTRAK
Status kesehatan ibu dan anak di Indonesia masih menjadi perhatian karena penurunan angka kematian ibu dan angka kematian bayi merupakan tujuan pembanguan kesehatan. Rendahnya kesadaran masyarakat akan pelayanan kesehatan oleh tenaga kesehatan merupakan faktor yang perlu diperhatikan. Penelitian ini bertujuan untuk mengetahui trend cakupan kunjungan ibu hamil (K4) dan pertolongan persalinan oleh tenaga kesehatan menurut kabupaten/kota di Provinsi Jawa Timur tahun 2011-2015. Desain penelitian yang digunakan adalah cross sectional. Hasil penelitian adalah cakupan K4 secara umum mengalami kenaikan, menunjukkan semakin baiknya akses masyarakat terhadap pelayanan kesehatan ibu hamil yang diberikan oleh tenaga kesehatan, begitupula dengan cakupan pertolongan persalinan oleh tenaga kesehatan mengalami peningkatan karena peningkatan pelayanan kesehatan ibu hamil karena diasumsikan ibu hamil yang mendapatkan pelayanan antenatal K4 kemungkinan persalinannya akan ditolong tenaga kesehatan. Kesimpulan dari penelitian ini adalah dalam kurun waktu 5 tahun (2011-2015), pola cakupan kunjugan ibu hamil (K4) dan pertolongan persalinan oleh tenaga kesehatan (Linakes) di Provinsi Jawa Timur cenderung mengalami kenaikan, diharapkan dengan meningkatnya cakupan pelayanan ibu hamil K4 akan meningkatkan cakupan pertolongan persalinan oleh tenaga kesehatan.
\end{abstract}

\title{
Kata Kunci: Tren, K4, Linakes, Jawa Timur
}

\section{PENDAHULUAN}

Dalam upaya peningkatan derajat kesehatan masyarakat, masih ditemukan tantangan besar dalam pembanguan kesehatan, yaitu penurunan Angka Kematian Ibu dan Angka Kematian Bayi. Sehingga di tahun 2012 Kementerian Kesehatan membuat program Expanding Maternal and Neonatal Survival (EMAS) untuk menurunkan angka kematian ibu dan bayi sebesar 25\%. (Kemenkes, 2014).

Program ini dilaksanakan di provinsi dan kabupaten dengan jumlah kematian ibu dan neonatal tertinggi. Salah satunya dengan upaya pelayanan kesehatan ibu hamil. Pelayanan kesehatan ibu hamil atau Antenatal Care (ANC) adalah salah satu upaya pencegahan awal dari faktor risiko kehamilan. Selain itu, ANC yang berkualitas dan persalinan yang aman juga dapat menurunkan jumlah kematian ibu hingga sekitar 87\% (Dwiana, 2014).

Indikator kualitas capaian pelayanan kesehatan ibu hamil dapat dinilai dari cakupan kunjungan ibu hamil (K4). Indikator cakupan K4 memperlihatkan akses pelayanan kesehatan terhadap ibu hamil dan tingkat kepatuhan ibu hamil dalam memeriksakan kehamilannya ke tenaga kesehatan. Cakupan K4 juga dapat menggambarkan cakupan pertolongan persalinan oleh tenaga kesehatan. Diasumsikan bahwa ibu hamil yang mendapatkan pelayanan antenatal K4 kemungkinan persalinannya akan ditolong tenaga kesehatan. Diharapkan dengan meningkatkan cakupan pelayanan kesehatan ibu hamil K4 akan meningkatkan cakupan pertolongan persalinan oleh tenaga kesehatan (Kemenkes, 2015).

Di Indonesia, kualitas pelayanan ANC masih rendah dilihat dari cakupan ANC yang masih dibawah target nasional dimana data cakupan kunjungan ibu hamil (K4) di Indonesia pada tahun 2015 sebesar $87,48 \%$ yang berarti belum mencapai target Renstra Kementerian Kesehatan pada tahun 2015 yaitu sebesar 95\%. Dari 34 provinsi di Indonesia, hanya 3 provinsi yang telah mencapai target tersebut, yaitu Kepulauan Riau, DKI Jakarta dan Jawa Barat (Kemenkes, 2015).

Berdasarkan data Pemantauan Wilayah Setempat (PWS) Kesehatan Ibu dan Anak (KIA), Provinsi Jawa Timur termasuk provinsi yang belum mencapai target renstra dengan cakupan kunjungan ibu hamil (K4) sebesar 91,24\%. Ini menunjukkan bahwa pemanfaatan pelayanan antenatal di fasilitas pelayanan 
kesehatan masih belum optimal, padahal pelayanan antenatal merupakan salah satu upaya yang dapat dilakukan dalam rangka menurunkan AKI dan AKB di Indonesia (Ulul, dkk, 2014).

Cakupan K4 juga menggambarkan cakupan pertolongan persalinan oleh tenaga kesehatan. Persentase pertolongan persalinan oleh tenaga kesehatan di Indonesia menunjukkan penurunan dari 90,88\% pada tahun 2013 menjadi 88,55\% pada tahun 2015 yang berarti belum mencapai target Renstra Kementerian Kesehatan pada tahun 2015 yaitu sebesar 90\% (Kemenkes, 2015).

\section{METODE PENELITIAN}

Desain penelitian ini adalah cross sectional dengan menggunakan data sekunder. Subjek dalam penelitian ini adalah data cakupan kunjungan ibu hamil (K4) dan pertolongan persalinan oleh tenaga kesehatan tahun 2011-2015 di Dinas Kesehatan Provinsi Jawa Timur.

Penelitian ini dilakukan di Dinas Kesehatan Provinsi Jawa Timur pada bulan september tahun 2016. Sumber data adalah laporan pemantauan wilayah setempat (PWS) kesehatan ibu dan anak (KIA) pada tahun 2011-2015 di Dinas Kesehatan Provinsi Jawa Timur.

Desain penelitian ini adalah cross sectional dengan menggunakan data sekunder. Subjek dalam penelitian ini adalah data cakupan kunjungan ibu hamil (K4) dan pertolongan persalinan oleh tenaga kesehatan tahun 2011-2015 di Dinas Kesehatan Provinsi Jawa Timur.

Penelitian ini dilakukan di Dinas Kesehatan Provinsi Jawa Timur pada bulan september tahun 2016. Sumber data adalah laporan pemantauan wilayah setempat (PWS) kesehatan ibu dan anak (KIA) pada tahun 2011-2015 di Dinas Kesehatan Provinsi Jawa Timur.

Analisis data menggunakan analisis deskriptif untuk memberikan gambaran pola cakupan kunjungan ibu hamil (K4) dan pertolongan persalinan oleh tenaga kesehatan menurut kabupaten/kota di
Provinsi Jawa Timur, kemudian digabungkan dalam satu diagram untuk melihat trend cakupan $\mathrm{k} 4$ dan linakes selama lima tahun (2011-2015).

\section{HASIL DAN PEMBAHASAN}

Penelitian ini bertujuan untuk mengetahui trend cakupan kunjungan ibu hamil (K4) dan pertolongan persalinan oleh tenaga kesehatan di provinsi Jawa Timur tahun 2011-2015. Hasil penelitian didapatkan pada gambar 1 terlihat capaian cakupan kunjungan ibu hamil K4 Provinsi Jawa Timur pada tahun 2011 adalah 88,25.

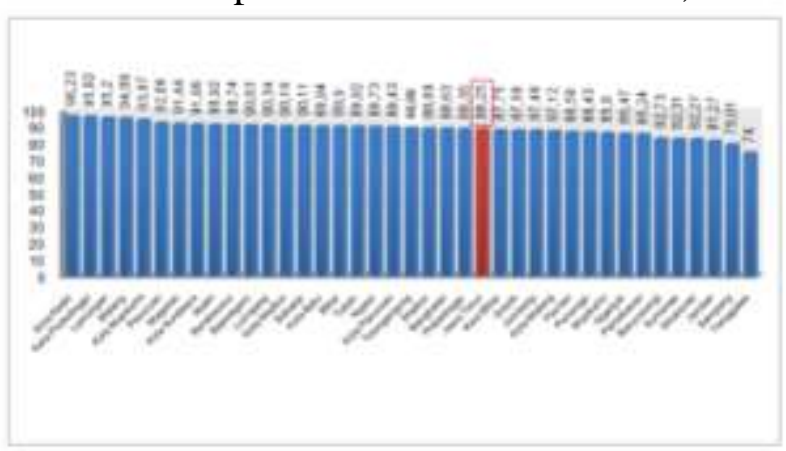

Gambar 1. Capaian Cakupan K4 Menurut Kabupaten/Kota di Provinsi Jawa Timur Tahun 2011

Capaian cakupan kunjungan ibu hamil (K4) tertinggi dimiliki oleh Kota Kediri yakni sebesar 96,23\% dan terendah dimiliki oleh Kabupaten Trenggalek yakni sebesar $74 \%$. Pada gambar 2 capaian cakupan K4 Provinsi Jawa Timur pada tahun 2012 adalah 84,38\%. Capaian ini mengalami penurunan jika dibandingkan dengan capaian tahun 2011.



Gambar 2. Capaian Cakupan K4 Menurut Kabupaten/Kota di Provinsi Jawa Timur Tahun 2012

Pada tahun 2012 capaian cakupan K4 tertinggi dimiliki oleh Kabupaten Lamongan yakni sebesar 101,55\%, 
sedangkan capaian terendah dimiliki oleh Kabupaten Jember memiliki yakni 70,67\%,

Pada gambar 3 terlihat capaian cakupan kunjungan ibu hamil (K4) Provinsi Jawa Timur pada tahun 2013 mengalami peningkatan dibanding tahun sebelumnya yakni sebesar $87,35 \%$.

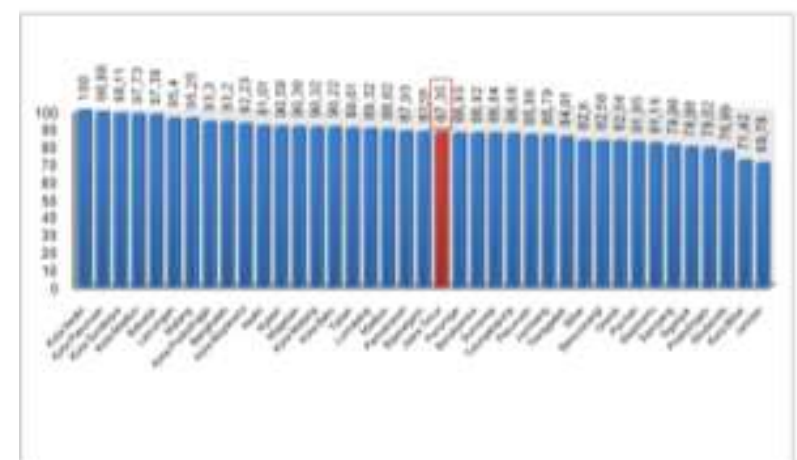

Gambar 3. Capaian Cakupan K4 Menurut Kabupaten/Kota di Provinsi Jawa Timur Tahun 2013

Capaian cakupan kunjungan ibu hamil (K4) tertinggi kembali dimiliki oleh Kota Kediri yakni mencapai $100 \%$ dan terendah dimiliki oleh Kabupaten Jember yakni sebesar 69,78\%.

Pada gambar 4 terlihat capaian cakupan kunjungan ibu hamil (K4) Provinsi Jawa Timur pada tahun 2014 sebesar $88,66 \%$. Capaian tahun 2014 ini juga mengalami peningkatan jika dibandingkan tahun 2013 yang mencapai 87,35\%.

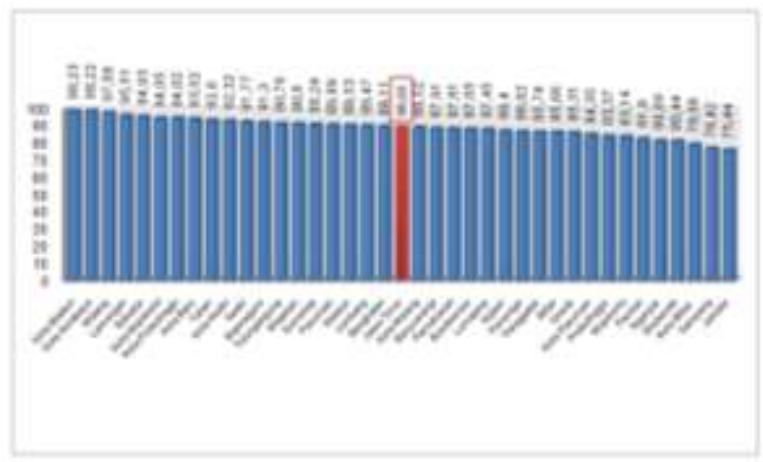

Gambar 4. Capaian Cakupan K4 Menurut Kabupaten/Kota di Provinsi Jawa Timur Tahun 2014

Capaian cakupan kunjungan ibu hamil (K4) tertinggi dimiliki oleh Kota Madiun yakni sebesar 98,23\% dan terendah kembali dimiliki oleh Kabupaten Jember yakni sebesar 75,44\%.

Capaian cakupan ibu hamil K4 Provinsi Jawa Timur pada tahun 2015 adalah 91,24 \%. Angka ini mengalami peningkatan dibandingkan tahun 2014 yang mencapai $88,66 \%$. Capaian cakupan ibu hamil K4 tertinggi dimiliki oleh Kota Surabaya yakni sebesar 98,41 \% dan terendah dimiliki oleh Kabupaten Nganjuk yakni sebesar 81,26\%. Hal ini terlihat pada gambar 5 berikut.

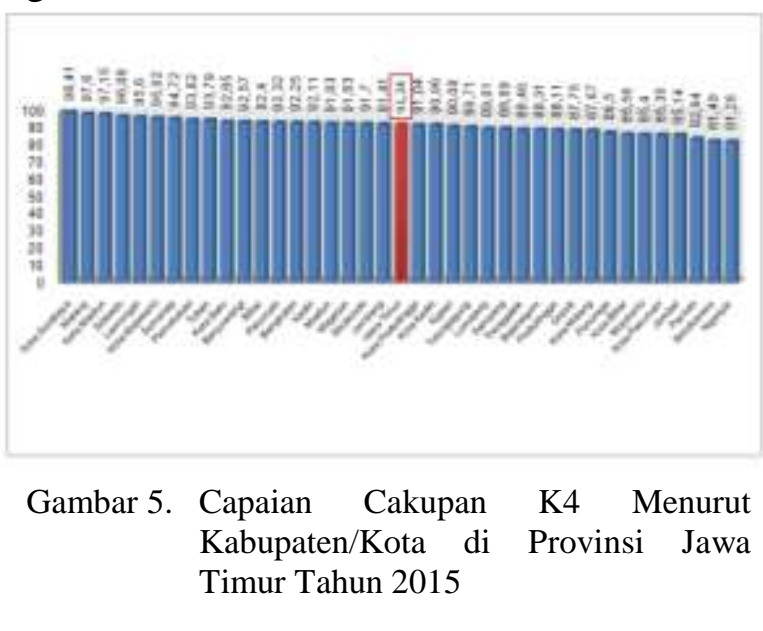

Cakupan K4 yang secara umum mengalami kenaikan setiap tahunnya kecuali pada tahun 2012. Penurunan capaian cakupan K4 pada tahun 2012 dikarenakan adanya perubahan data sasaran program, yakni sasaran ibu hamil yang bersumber dari data estimasi BPS Provinsi Jawa Timur.

Seperti terlihat pada gambar 6, Peningkatan capaian cakupan K4 di Provinsi Jawa Timur selama lima tahun mengindikasikan semakin baiknya akses masyarakat terhadap pelayanan kesehatan ibu hamil yang diberikan oleh tenaga kesehatan. Cakupan K4 juga dapat menggambarkan cakupan pertolongan persalinan oleh tenaga kesehatan (linakes).

Cakupan pertolongan persalinan oleh tenaga kesehatan (linakes) pada tahun 2011 di provinsi Jawa Timur adalah sebesar $95,95 \%$.

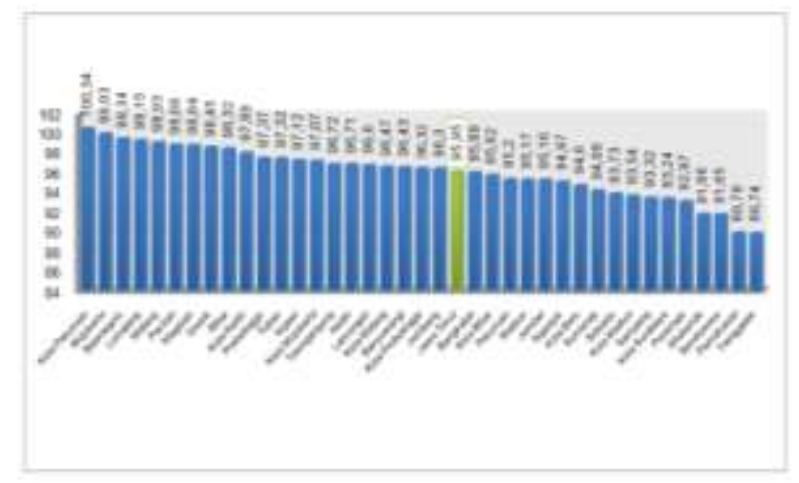


Gambar 7. Capaian Cakupan Linakes Menurut Kabupaten/Kota di Provinsi Jawa Timur Tahun 2011

Pada gambar 7 diatas terlihat capaian cakupan linakes tertinggi pada tahun 2011 dimiliki oleh Kota Pasuruan yakni sebesar
$100,34 \%$ dan capaian linakes terendah dimiliki oleh Kabupaten Trenggalek yakni sebesar $89,74 \%$.

Penurunan capaian terjadi pada tahun 2012 karena capaian cakupan Linakes turun menjadi $84,38 \%$.



Gambar 6. Capaian Cakupan K4 Provinsi Jawa Timur Tahun 2011-2015

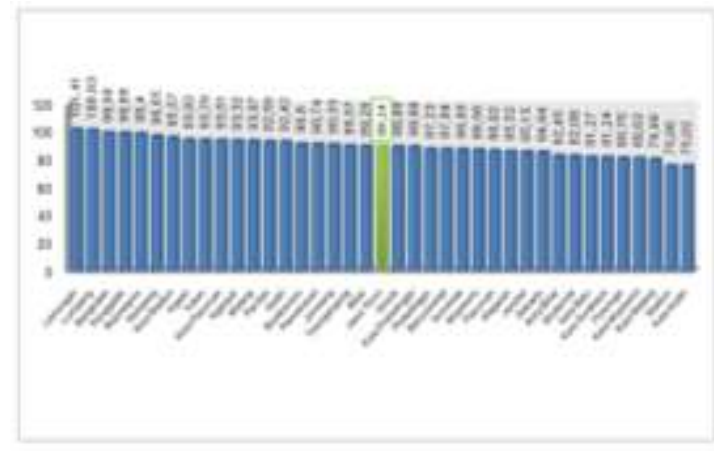

Gambar 8. Capaian Cakupan Linakes Menurut Kabupaten/Kota di Provinsi Jawa Timur Tahun 2012

Capaian ini mengalami banyak penurunan jika dibandingkan pada tahun 2011. Capaian cakupan linakes tertinggi dimiliki oleh Kabupaten Lamongan yakni sebesar 100,41 \% dan terendah dimiliki oleh Kota Kediri yakni sebesar 75,02\%.

Di tahun 2013 terjadi peningkatan capaian cakupan linakes di Provinsi Jawa Timur yakni sebesar $92,09 \%$. Seperti yang terlihat pada gambar 9 berikut.

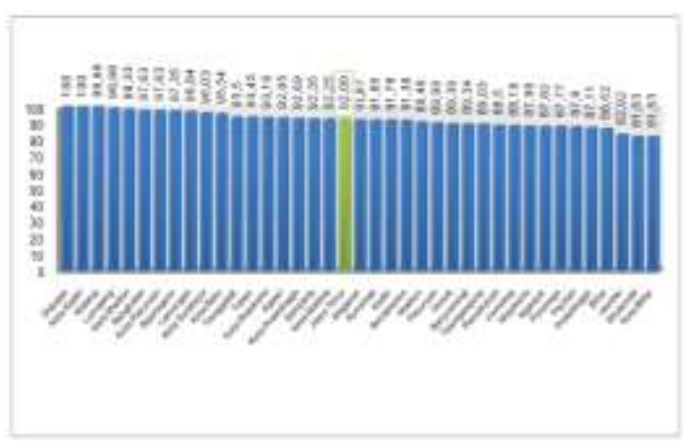

Gambar 9. Capaian Cakupan Linakes Menurut Kabupaten/Kota di Provinsi Jawa Timur Tahun 2013

Capaian cakupan linakes tertinggi dimiliki oleh Kabupaten Sidoarjo yakni sebesar $100 \%$ dan terendah dimiliki oleh Kota Blitar yakni sebesar 81,53\%.

Capaian cakupan pertolongan persalinan oleh tenaga kesehatan (Linakes) untuk Provinsi Jawa Timur pada tahun 2014 mencapai 92,45\%. Angka ini mengalami peningkatan dibandingkan tahun 2013 yang mencapai 92,04\%.

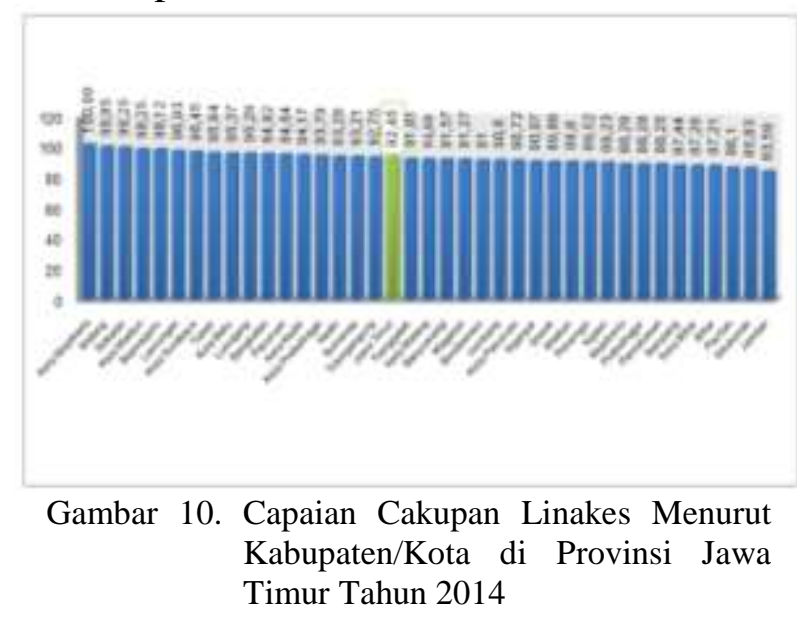

Capaian cakupan linakes tertinggi pada tahun 2014 dimiliki oleh Kota Mojokerto yakni sebesar 100,99 \% dan terendah dimiliki oleh Kbaupaten Jember yakni sebesar 83,59\%. 
Capaian cakupan pertolongan persalinan oleh tenaga kesehatan (Linakes) untuk Provinsi Jawa Timur pada tahun 2015 mencapai 95,81\%. Angka ini mengalami peningkatan dibandingkan tahun 2014 yang mencapai $92,45 \%$.



Gambar 11. Capaian Cakupan Linakes Menurut Kabupaten/Kota di Provinsi Jawa Timur Tahun 2015
Capaian cakupan linakes tertinggi pada tahun 2014 dimiliki oleh Kota Sampang yakni sebesar 100,65 \% dan terendah dimiliki oleh Kabupaten Bondowoso yakni sebesar $86,15 \%$.

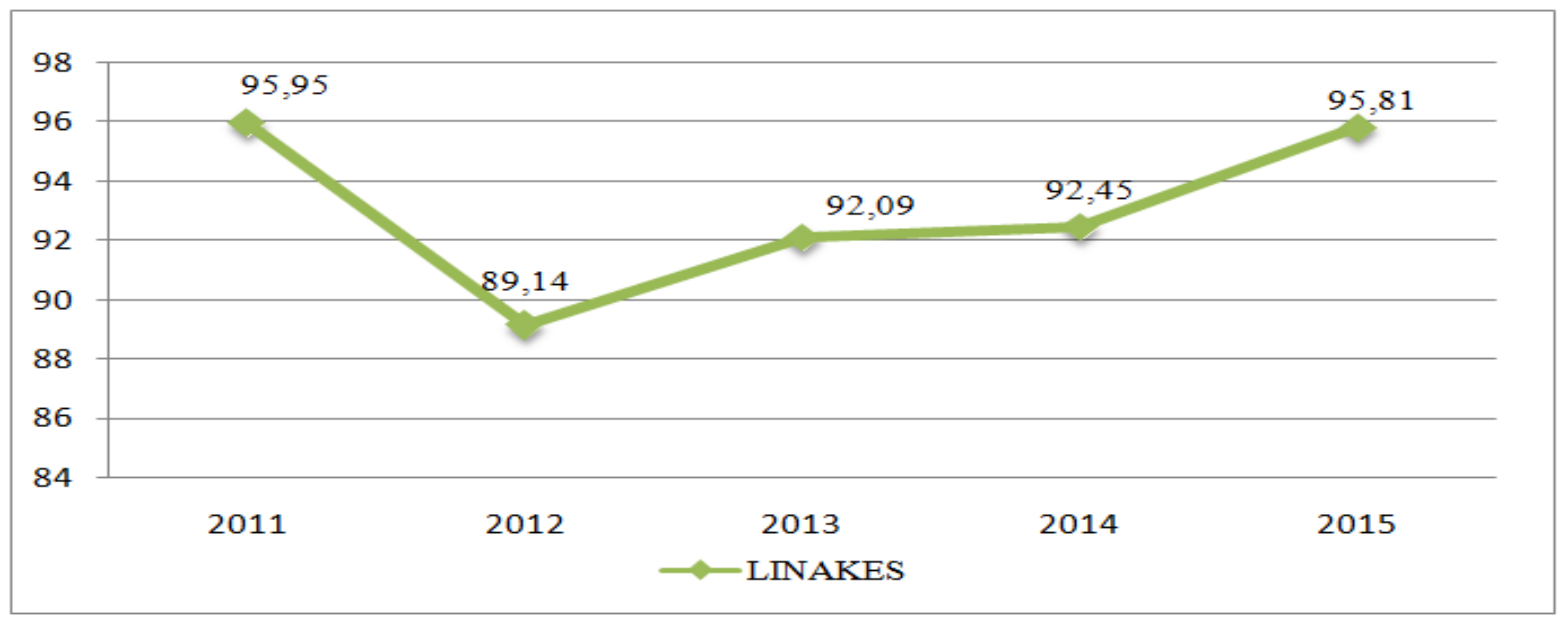

Gambar 12. Capaian Cakupan Linakes Provinsi Jawa Timur Tahun 2011-2015

Cakupan pertolongan persalinan oleh tenaga kesehatan mengalami peningkatan dari tahun 2011 sampai dengan tahun 2015. Namun terdapat pengecualian di tahun 2012 yang mengalami penurunan capaian. Salah satu penyebabnya adalah karena perubahan sasaran Ibu Bersalin (Bulin) yang disesuaikan dengan data sasaran BPS Provinsi Jawa Timur (Dinkes, 2014). Namun, dari sisi angka absolut (jumlah) capaian Jawa Timur mengalami kenaikan dibandingkan tahun sebelumnya, seperti yang terlihat pada gambar 12 diatas.

\section{PEMBAHASAN}

Berdasarkan Undang-Undang nomor 36 tahun 2009 tentang kesehatan bahwa upaya kesehatan ibu ditujukan untuk menjaga kesehatan ibu sehingga mampu melahirkan generasi yang sehat dan berkualitas. untuk mengukur status kesehatan ibu pada suatu wilayah, salah satunya dengan indikator angka kematian ibu (AKI).

Pemerintah sejak tahun 1990 telah melakukan upaya strategis dalam upaya menekan AKI, Salah satunya dengan pelayanan kesehatan ibu. Pelayanan kesehatan ibu hamil diberikan kepada ibu hamil yang dilakukan oleh tenaga kesehatan di fasilitas pelayanan kesehatan. Pelayanan ini dilakukan selama rentang usia kehamilan ibu berdasarkan usia kehamilan yakni trimester pertama, trimester kedua, dan trimester ketiga (Kemenkes, 2016). 
Pada program kesehatan ibu terdapat beberapa capaian indikator antara lain cakupan $\mathrm{K} 4$ dan pertolongan persalinan oleh tenaga kesehatan. Cakupan K4 adalah jumlah ibu hamil yang sudah mendapatkan pelayanan antenatal sesuai dengan standar yakni paling sedikit empat kali sesuai jadwal yang dianjurkan di tiap trimester dibandingkan jumlah sasaran ibu hamil di satu wilayah kerja dalam kurun waktu satu tahun (Kemenkes, 2016).

Indikator tersebut juga menggambarkan akses terhadap pelayanan kesehatan dan tingkat kepatuhan ibu hamil dalam memeriksakan kehamilannya ke tenaga kesehatan (Kemenkes, 2016). Cakupan K4 juga memberikan gambaran ibu hamil yang telah mendapatkan pelayanan ibu hamil sesuai standar dan paling sedikit empat kali kunjungan.

Capaian cakupan $\mathrm{K} 4$ provinsi Jawa Timur pada tahun 2011 adalah 88,25. Capaian ini belum memenuhi target yang telah ditetapkan di tahun 2011 yakni $91 \%$. Lebih dari $50 \%$ tepatnya 28 Kabupaten/Kota yang belum mencapai target. Penurunan terjadi ditahun 2012 karena capaian cakupan K4 Provinsi Jawa Timur pada tahun 2012 adalah 84,38\%, sedangkan target Provinsi Jawa Timur untuk cakupan kunjungan ibu hamil (K4) pada tahun 2012 adalah $92 \%$ dengan kondisi 28 kabupaten/kota masih di bawah target provinsi (Dinkes, 2013).

Capaian cakupan kunjungan ibu hamil (K4) Provinsi Jawa Timur pada tahun 2013 sebesar 87,35\%. Nilai cakupan ini tidak dapat mencapai target renstra tahun 2013 yakni sebesar 93\%. Namun demikian, terdapat 7 dari $38(18,42 \%)$ kabupaten/kota di provinsi Jawa Timur yang dapat mencapai target tersebut pada tahun 2013 antara lain Kabupaten Malang, Kabupaten Lamongan, Kota Madiun, Kabupaten Lumajang, Kabupaten Ngawi dan Kabupaten Bangkalan.

Capaian cakupan kunjungan ibu hamil (K4) Provinsi Jawa Timur pada tahun 2014 sebesar 88,66\%. Capaian ini meningkat di tahun 2015 karena cakupan ibu hamil K4 Provinsi Jawa Timur pada tahun 2015 adalah 91,24\%.

Meskipun mengalami peningkatan secara nasional cakupan K4 yang belum dapat mencapai target Renstra tahun 2015, yakni $95 \%$. Ini menunjukkan akses pelayanan kesehatan terhadap ibu hamil dan tingkat kepatuhan ibu hamil dalam memeriksakan kehamilannya ke tenaga kesehatan belum juga optimal.

Berbagai program dan kegiatan telah dilaksanakan untuk mendekatkan akses pelayanan kesehatan yang berkualitas kepada masyarakat hingga ke pelosok desa, salah satunya dengan meningkatkan cakupan pelayanan antenatal. Upaya ini dilakukan antara lain dari segi sarana dan fasilitas pelayanan kesehatan dan upaya kesehatan Bersumberdaya Masyarakat (UKBM) seperti Poskesdes dan Posyandu.

Selain itu juga dilakukan penempatan bidan di desa dan dengan diperkuat adanya Bantuan Operasional Kesehatan (BOK) sejak tahun 2010 dan diluncurkannya Jaminan Persalinan (Jampersal) sejak tahun 2011 (Kemenkes, 2016).

Namun kendala yang dihadapi dalam pelaksanaan pelayanan kesehatan ibu hamil tidak hanya dari sisi akses. Kualitas pelayanan yang diberikan juga harus ditingkatkan, di antaranya pemenuhan semua komponen pelayanan kesehatan ibu hamil harus diberikan saat kunjungan (Kemenkes, 2016).

Cakupan K4 juga dapat menggambarkan cakupan pertolongan persalinan oleh tenaga kesehatan. Selain itu upaya lain untuk menurunkan kematian ibu dan kematian bayi yaitu dengan mengupayakan agar setiap persalinan ditolong oleh tenaga kesehatan terlatih antara lain dokter spesialis kebidanan dan kandungan (SpOG), dokter umum, dan bidan, serta diupayakan dilakukan di fasilitas pelayanan kesehatan (Kemenkes, 2016).

Pertolongan persalinan dimulai pada kala I sampai dengan kala IV persalinan. Keberhasilan program ini dapat diukur 
melalui indikator persentase pertolongan persalinan oleh tenaga kesehatan terlatih (Cakupan PN) dan persentase persalinan di fasilitas pelayanan kesehatan (cakupan PF).

Selain itu indikator cakupan PN juga dapat memperlihatkan tingkat kemampuan pemerintah dalam menyediakan pelayanan persalinan berkualitas oleh tenaga kesehatan terlatih. Karena komplikasi dan kematian ibu dan bayi baru lahir sebagian besar terjadi ketika persalinan.

Capaian cakupan pertolongan persalinan oleh tenaga kesehatan (Linakes) untuk Provinsi Jawa Timur pada tahun 2011 adalah 95,95\%. Capaian ini sudah melebihi target Renstra di tahun 2011 yakni sebesar $86 \%$, dan Provinsi Jawa Timur termasuk dalam 12 provinsi dengan capaian tertinggi di Indonesia.

Namun hal ini berbanding terbalik dengan yang terjadi di tahun 2012, karena capaian cakupan Linakes untuk Provinsi Jawa Timur pada tahun 2012 adalah $89,14 \%$. Angka ini di bawah target yang telah ditentukan yakni $94 \%$.

Dari 38 kabupaten/kota hanya 7 (tujuh) kabupaten/kota yang mencapai target, yaitu Kabupaten Lamongan, Kabupaten Lumajang, Kabupaten Bangkalan, Kabupaten Trenggalek, Kabupaten Bojonegoro, Kabupaten Sampang dan Kota Madiun. Selain itu penurunan capaian di tahun 2012, juga disebabkan adanya perubahan sasaran Ibu Bersalin (Bulin) yang disesuaikan dengan data sasaran BPS Provinsi Jawa Timur.

Pencapaian cakupan linakes juga dipengaruhi adanya Pertolongan Persalinan oleh Dukun (Lindukun) yang masih terjadi di beberapa kabupaten/kota di Jawa Timur. Karena di Kabupaten Bangkalan dan Kabupaten Sampang, meskipun sudah mencapai target Linakes namun cakupan Lindukun masih cukup besar dengan kisaran antara $3-6 \%$. Keadaan ini juga dapat disebabkan karena akses pelayanan yang kurang memadai, letak geografis serta jumlah dukun yang relatif masih banyak (Dinkes, 2013).
Pada tahun 2013 presentase persalinan ditolong tenaga kesehatan di Provinsi Jawa Timur mencapai 92,09\%. Capaian provinsi Jawa Timur tersebut dapat memenuhi target renstra tahun 2013 yang sebesar $89 \%$. Namun demikian, masih terdapat 11 kabupaten/kota di provinsi Jawa Timur yang tidak dapat mencapai target tersebut pada 2013.

Pada tahun 2014, target untuk program linakes adalah $95 \%$. Dengan kondisi ini, angka cakupan linakes Provinsi Jawa Timur masih belum mencapai target. Karena pada tahun 2014 capaian cakupan linakes mencapai 92,45\%.

Dari 38 kabupaten/kota di Provinsi Jawa Timur hanya 10 kabupaten/kota telah mencapai target. Sehingga diperlukan upaya percepatan untuk meningkatkan cakupan linakes. Karena secara tidak langsung kematian ibu juga terkait erat dengan penolong persalinan. Persalinan yang ditolong tenaga kesehatan berkontribusi terhadap menurunya risiko kematian ibu dan bayi. Demikian pula dengan tempat persalinan, jika persalinan dilakukan di fasilitas kesehatan, juga akan semakin menekan risiko kematian ibu. Oleh karena itu, Kementerian Kesehatan tetap menerapkan kebijakan bahwa seluruh persalinan harus ditolong oleh tenaga kesehatan dan dilakukan di fasilitas kesehatan (Kemenkes, 2016).

Upaya - upaya yang dlakukan telihat di tahun 2015 karena capaian linakes di tahun 2015 mengalami peningkatan yakni sebesar 95,81\%. Dengan kondisi ini, angka cakupan Provinsi Jawa Timur sudah mencapai target (95\%). Dari 38 kabupaten/kota, hanya 20 kabupaten/kota yang sudah mencapai target.

Cara mengatasi permasalahan ini sehingga mencapai target adalah dengan melakukan pemetaan dan pemantauan ibu hamil dengan melibatkan multi pihak. Salah satu nya dengan adanya Kebijakan Dana Alokasi Khusus (DAK) Bidang Kesehatan menggariskan bahwa pembangunan Puskesmas harus satu paket dengan rumah dinas tenaga kesehatan. 
Begitupula dengan pembangunan Poskesdes yang harus bisa sekaligus menjadi rumah tinggal bagi bidan di desa. Diharapkan tenaga kesehatan termasuk bidan akan siaga di tempat tugasnya. Untuk daerah dengan akses ke pelayanan kesehatan yang sulit, juga dikembangkan program kemitraan Bidan dan Dukun serta dibentuknya Rumah Tunggu Kelahiran.

Selain itu salah satu hal yang menjadi alasan seorang ibu melahirkan di rumah dan dibantu oleh dukun adalah kurangnya biaya. Hal ini dibuktikan oleh beberapa penelitian ilmiah salah satunya yang dilakukan oleh Women Research Institute di tahun 2007-2008 pada tujuh kabupaten/kota di Indonesia.

Oleh karena itu, Menyadari hal tersebut, Kementerian Kesehatan sejak tahun 2011 meluncurkan Jaminan Persalinan (Jampersal) yang merupakan jaminan pembiayaan yang dapat digunakan sejak pemeriksaan kehamilan, pertolongan persalinan, hingga pelayanan nifas termasuk pelayanan bayi baru lahir dan KB pasca persalinan (Kemenkes, 2016).

Diharapkan semakin kuatnya kerja sama dan sinergi berbagai program yang dilakukan oleh Pemerintah, Pemerintah Daerah, dan masyarakat termasuk sektor swasta, diharapkan dapat mendorong tercapainya target cakupan pelayanan antenatal dan pertolongan persalinan oleh tenaga kesehatan yang berkualitas, sekaligus menurunkan Angka Kematian Ibu (AKI) dan Angka Kematian Bayi khususnya di Jawa Timur.

\section{SIMPULAN DAN SARAN}

\section{Simpulan}

1. Dalam kurun waktu 5 tahun (20112015), pola cakupan kunjugan ibu hamil (K4) dan pertolongan persalinan oleh tenaga kesehatan (Linakes) di Provinsi Jawa Timur cenderung mengalami kenaikan.

2. Pada tahun 2012 terjadi penurunan capaian dikarenakan adanya perubahan data sasaran program, yakni sasaran ibu hamil yang bersumber dari data estimasi BPS Provinsi Jawa Timur.

3. Capaian cakupan pertolongan persalinan oleh tenaga kesehatan cenderung mengalami peningkatan kecuali di tahun 2012 karena penyebab yang sama. Namun capaian linakes kembali meningkat di tahun 2013 yakni sebesar 92,09 dan 92,45 di tahun 2014. Pada tahun 2015 mencapai 95,81\%.

\section{Saran}

Saran yang dapat diberikan adalah dengan adanya data tentang pencapaian program upaya kesehatan ibu yakni cakupan pelayanan kesehatan ibu hamil (K4) dan pertolongan persalinan oleh tenaga kesehatan selama lima tahun terakhir, dapat digunakan sebagai sarana untuk memonitoring dan mengevaluasi program kesehatan yang telah atau sedang dilakukan dalam rangka meningkatkan pelayanan kesehatan ibu maternal dan menurunkan angka kematian ibu dan angka kematian bayi di Jawa Timur

Selain itu perlu adanya upaya terobosan dan penelitian-penelitian baru, yang nantinya dapat menghasilkan suatu publikasi informasi dan data pembangunan kesehatan, serta dapat membawa manfaat bagi dunia kesehatan di Jawa Timur dan Indonesia pada umumnya.

\section{DAFTAR PUSTAKA}

Arief, M. A., Noerdin, E., Agustini, E., Aripurnami, S., Wahyumi, S., 2010.Target MDGs Menurunkan Angka Kematian Ibu Tahun 2015 Sulit Dicapai. Jakarta: Woman Research Institute. Tersedia di: $<$ http://wri.or.id/files/ Buku_ Target_MDGs_Penurunan_AKI_S ulit\%20Dicapai.pdf.> [diakses tanggal 10 April 2016].

Arsyad, S.,2009. Kematian Ibu di Indonesia Analisis Data Survei Demografi dan kesehatan Indonesia Tahun 19942007 : Puslitbang Keluarga Sejahtera dan Peningkatan Kualitas Perempuan, BKKBN. Tersedia 
di:http://ejournal.persagi.org/go/ind ex.php/Gizi_Indon/article/downloa $\underline{\mathrm{d} / 68 / 65>}$ [diakses tanggal 10 April 2016].

Departemen Kesehatan RI, 2009. Pedoman Pemantauan Wilayah Setempat Kesehatan Ibu dan Anak (PWSKIA). Jakarta : Departemen Kesehatan RI.

Dinas Kesehatan Provinsi Jawa Timur. Profil Kesehatan Provinsi Jawa Timur Tahun 2011. Surabaya: Dinas Kesehatan Provinsi Jawa Timur.

Dinas Kesehatan Provinsi Jawa Timur. Profil Kesehatan Provinsi Jawa Timur Tahun 2012. Surabaya: Dinas Kesehatan Provinsi Jawa Timur.

Dinas Kesehatan Provinsi Jawa Timur. Profil Kesehatan Provinsi Jawa Timur Tahun 2013. Surabaya: Dinas Kesehatan Provinsi Jawa Timur.

Dinas Kesehatan Provinsi Jawa Timur. Profil Kesehatan Provinsi Jawa Timur Tahun 2014. Surabaya: Dinas Kesehatan Provinsi Jawa Timur.

Dharmayanti, Ika, dkk. 2014. Trens Pemanfaatan Penolong Kelahiran Di Indonesia (Analisis Data Susenas Tahun 2001, 2004 dan 2007). Vol. 17 No. 03 Juli 2014: 297-307. [Diakses tanggal 10 November 2016].

Hoelman, Mickael, dkk. 2015. Panduan SDGs Untuk Pemerintah Daerah (Kota dan Kabupaten) dan Pemangku Kepentingan Daerah.infid.

Ika, Arulita. 2007. Faktor-Faktor yang Mempengaruhi Kematian Maternal (Studi kasus di Kabupaten Cilacap. Tesis. Universitas Diponegoro. Tersedia di:<http://eprints.undip.ac. id/4421/1/arulita.pdf $>$ [Diakses tanggal 1 mei 2016].

Kementerian Kesehatan RI. 2014. Profil Kesehatan Indonesia Tahun 2014. Jakarta : Kementerian Kesehatan RI.

Kementerian Kesehatan RI. 2015. Profil Kesehatan Indonesia Tahun 2015. Jakarta: Kementerian Kesehatan RI.
Kementerian Kesehatan RI.2012. InfoDatin Mothers Day. Pusat Data dan Informasi. Kementerian Kesehatan RI. Tersedia di:< http://www.depkes.go.id/download. php?file=download/pusdatin/infoda tin/infodatin-ibu.pdf> [Diakses tanggal 1 Mei 2016].

Kementerian Kesehatan RI . 2015. Laporan Akuntabilitas Kinerja Direktorat Bina Kesehatan Ibu Tahun Anggaran 2014. Kementerian Kesehatan RI

Laporan Akuntabilitas Kinerja Kementerian Kesehatan RI

Maftuchan, dkk. 2013. Refleksi Upaya Pencapaian MDGs 4\&5 di Daerah Menjelang 2015. Prakarsa

Manuaba, I.A.C. 2009. Memahami Kesehatan Reproduksi Wanita. edisi 2. Jakarta:EGC.

Mariyani D. 2010. Faktor-faktor yang Memengaruhi Pelaksanaan Pelayanan Antenatal Sesuai Standar Pelayanan Kebidanan oleh Bidan Desa di Kabupaten Bima Tahun 2010. Thesis. Universitas Diponegoro. [Diakses tanggal 01 Desember 2015].

Saifuddin, A. 2002. Buku Panduan Praktis Pelayanan Kesehatan Maternal dan Neonatal. Jakarta: Yayasan Bina Pustaka Sarwono Prawiroharjo. 